\title{
РАННИЕ ДНЕВНИКИ ЛЬВА ТОЛСТОГО КАК АВТОПРЕТЕКСТ ИСПОВЕДИ
}

\author{
LUDMIŁA ŁUCEWICZ \\ Uniwersytet Warszawski \\ Wydział Lingwistyki Stosowanej \\ Instytut Komunikacji Specjalistycznej i Interkulturowej \\ ul. Szturmowa 4, 02-678 Warszawa, Polska \\ e-mail: ludmilalucewicz@gmail.com \\ ORCID: https://orcid.org/0000-0002-6340-2598 \\ (nadesłano 6.07.2018; zaakceptowano 14.08.2018)
}

\section{Abstract \\ The early diaries of Leo Tolstoy as a basis of My Confesion}

The author of the article proceeds from the fact that the tendency to autobiographical confession is Leo Tolstoy's characteristic feature at all stages of his creative activity. The desire to deepen self-knowledge, to determine the purpose in life and his own faith, to influence the nature of self-development in terms of self-improvement, to create a personality worthy of self-esteem, was most fully expressed in the diaries of the Russian writer. The article shows that in the early diaries (1847-1855), the experience of selfobservation determines the confessional-autobiographical discourse. Moreover, the very motivation of a number of records (about consciousness, self-knowledge, faith, religion, God) is, in a way, actualized in My Confession (1879-1882). These observations give grounds to raise the question if My Confession is based on Leo Tolstoy's early diaries.

\section{Key words}

Leo Tolstoy, early diaries, self-knowledge, faith, God, My Confession, basis. 


\section{Резюме}

Автор статьи исходит из того, что тенденция к автобиографической исповедальности - это характерная черта Льва Толстого, присущая ему на всех этапах творческой деятельности. Стремление глубже познать самого себя, определить цель в жизни и свое предназначение, повлиять на характер саморазвития в плане самосовершенствования, создать из себя личность, достойную самоуважения, получило наиболее полное выражение в дневниках русского автора. В статье показано, что в ранних дневниках (1847-1855) писателя, во-первых, опыт самонаблюдений обусловливает исповедально-автобиографический дискурс; а во-вторых, самая мотивика ряда записей (о сознании, самопознании, вере, религии, Боге) так или иначе актуализируется в Исповеди (1879-1882). Эти наблюдения дают основания поставить вопрос о ранних дневниках Льва Толстого как автопретексте его Исповеди.

\section{Ключевые слова}

Лев Толстой, ранние дневники, самопознание, вера, Бог, Исповедь, автопретекст.

Тенденция к автобиографической исповедальности - характерная черта Льва Толстого, присущая ему на всех этапах творческой деятельности. Дмитрий Мережковский в свое время подчеркивал, что «едва ли найдется другой писатель, который обнажал бы самую частную, личную, иногда щекотливую сторону жизни своей с такою великодушною или беззастенчивою откровенностью, как Толстой» (Мережковский, 1995, с. 13), он же отмечал теснейшую связь художественного нарратива с состоянием внутреннего мира писателя, когда «самые подробные (...) исповеди, покаяния, признания, (...) позволяют следить за каждым движением его сознания и совести» (Мережковский, 1995, с. 27), а художественное наследие Толстого в целом воспринимал как «одну бесконечно подробную „исповедь” (Мережковский, 1995, с. 13). Близок к Мережковскому в трактовке творчества русского писателя и известный австрийский прозаик Стефан Цвейг, утверждавший, что «...проза Толстого является не чем иным, как единой, тянущейся вдоль целой жизни, картина за картиной, постоянно пополняющей себя огромной исповедью» (Цвейг, 1992). Самую же Исповедь писателя ${ }^{1}$ Мережковский называл произведением «жгуче-покаянным и самобичующим» (Мережковский, 1995, с. 14), а Цвейг видел в ней ярко выраженное толстовское «стремление к самоизображению», которое «превращалось в фанатическое и флагеллантское наслаждение самобичеванием», «насильственное, судорожное посрамление собственной жизни» (Цвейг, 1992).

1 Об истории создания и издания Исповеди см.: Гусев, 1970, с. 142-157; Балдин, 2000, с. 24-32; Луцевич, 2010, с. 467-486; Луцевич, 2017, с. 7-37. 
Эти же свойства - исповедальность, автобиографичность, откровенность, покаянность, самокритика - наиболее презентативные черты ранних дневников $^{2}$ русского автора.

Желание как можно глубже познать самого себя (в собственных достоинствах, но и в значительно большей степени в личных недостатках и даже «пороках» ради избавления от них), определить свое предназначение, повлиять на характер дальнейшего саморазвития, создать, сформировать из себя личность, достойную самоуважения возникло у Толстого достаточно рано. Наиболее адекватной словесной формой, дававшей возможности для воплощения скрупулезного самонаблюдения, самоанализа, самопознания, направленных в конечном счете на решение задачи самосовершенствования, и стали для него дневники.

К ведению дневников Толстой приступил в юности (1847) и продолжал с некоторыми перерывами до последних дней своей жизни (1910). Значение собственных Дневников писатель в записи от 19 марта 1906 г. определил так:

Думал о том, что пишу я в дневнике не для себя, а для людей, преимущественно для тех, которые будут жить, когда меня - телесно - не будет, и что в этом нет ничего дурного. Это - то, что мне думается, что от меня требуется. Ну, а если сгорят эти дневники? Ну что ж. Они нужны, может быть, для других, а для меня наверное не то, что нужны, а они - я. Они доставляют мне благо (Толстой, 1978-1985, т. 22, с. 216)³.

Толстой, как видно, полностью отождествлял себя со своими дневниками, видя в них безусловную ценность (благо) для себя. Это же отметил и Стефан Цвейг, подчеркнув, что в течение шестидесяти творческих лет, начиная с раннего возраста, «стихийная любознательность» Толстого была направлена преимущественно на самого себя (Цвейг, 1992).

Исследователи неоднократно указывали на значимость толстовских дневников (особенно раннего периода) для понимания сложных интеллектуальнопсихических и творческих процессов в становлении и развитии писателя. Так, Василий Зеньковский справедливо отмечал, что «для изучения генезиса различных построений Толстого много дают его дневники (особенно Дневник молодоcти...)» (Зеньковский, 1991, с. 199). Борис Эйхенбаум видел в дневнике молодого Толстого выработку методологии самонаблюдения как подготовительной ступени к художественному творчеству (Эйхенбаум, 1922, с. 29), Сильвия Зассе - программу личного воспитания (Зассе, 2012, с. 141), Георгий Ореханов - «нечто самое главное в области его личной веры» (Ореханов, 2016, с. 173). Иоанна Пиотровска обнаружила «существенные сходства между дневниками Толстого 1840-1850-х гг. и руссоиской Исповедью» (Пиотровска, 2008, с. 94). Владимир Бибихин, выявляя сложный характер взаимоотношений между расслаивающимися дневниковыми толстовскими Я, пытался уяснить, каким образом в дневнике

2 См. о дневниках Толстого: Галаган, 2000, с. 188-194; Галаган, 2007, с. 8-9; Егоров, 2002, c. 158-192; Паперно, 2003, с. 296-317; Егоров, 2004, с. 117-123; Булдакова, 2005, с. 77-88; Бушканец, 2006, с. 165-177; Gazdecka, 2006, с. 179-186; Пиотровска, 2007, с. 39-43; Пиотровска, 2008, с. 503-512; с. 47-55; с. 93-100; Бибихин, 2014, с. 35-47, с. 48-76; Тарасов, с. 77-109.

3 Здесь и далее, кроме особо оговоренных случаев, произведения Толстого цитируются в тексте в скобках с указанием номера тома и номера страницы по изданию: Толстой, 1978-1985. 
писатель «обращается напрямую с собой», и показать, что «сам он не он сам без этого глядящего в дневнике на него самого» (Бибихин, 1988, с. 55). Справедливы наблюдения профессора Принстонского университета Ричарда Густафсона: «подлинная миссия Толстого - это его постоянная попытка выразить свое я и найти собственное предназначение» (Густафсон, 2003, с. 20), а также современного издателя, которого дневники Толстого поразили «своей предельной искренностью» - исповедальностью (Петровицкая, 2009, с. 9).

На мой взгляд, в ранних дневниках (1847-1855) писателя, во-первых, опыт самонаблюдений обусловливает исповедально-автобиографический дискурс; а во-вторых, самая мотивика ряда записей (о сознании, самопознании, вере, религии, Боге) так или иначе актуализируется в Исповеди (1879-1882). Эти наблюдения и дают основания поставить вопрос о ранних дневниках Льва Толстого как автопретексте его Исповеди.

В середине 1840-х гг., в период своего студенчества, увлекшись идеей самосовершенствования, Толстой начал составлять для себя всевозможные правила, «которым старался следовать» (Толстой, 1978-1985, т. 16, с. 109). 16-го февраля 1847 г. он записывает основные Правила в жизни, где рассматривает деятельность человека «в трех отношениях. 1) в отношении к Высшему существу. 2) в отношении к равным себе существам и 3) в отношении к самому себе» (Толстой, 1937, с. 263). Отношение человека к Богу автор видит в решении трех взаимосвязанных задач: «а) (...) что есть Бог, b) что есть человек и с) какие могут б[ыть] отношения между Богом и человеком» (Толстой, 1937, с. 263). Далее поясняет:

Чтобы составить себе понятие о Боге, взглянем сначала на свои душевные способности, а потом на природу4. В душе человек находит чувство самосознания, которое первенствует в душе нашей; рядом с ним мы найдем чувство столь же сильное - чувство сознания высшего существа (Толстой, 1937, с. 263).

Эта запись знаменательна, поскольку фиксирует доминанты внутреннего развития личности автора и характера его творческой деятельности. Согласно юному Толстому, душа человека осознает прежде всего себя, но, наряду с самоосознанием, сосуществует сильное чувство сознания Бога. Толстовские дневники станут для писателя лабораторией непрестанного самоосознания собственной личности, а его Исповедь ознаменует попытку переключения внимания с себя на «высшее существо».

Приступая к ведению дневника 17 марта 1847 г., восемнадцатилетний автор, оказавшись в тот момент на больничной койке в клинике, рад тому, что он «совершенно один» и ему «никто не мешает» «уяснить свой взгляд на вещи»; уединение позволяет отключиться от всего постороннего и «взойти самому в себя» (Толстой, 1978-1985, т. 21, с. 7), сосредоточиться на собственной личности, наблюдая, как «жизнь прорастает через все (...) и за этим смотрит как смотритель, теоретик, пишущий дневник» (Бибихин, 2012, с. 59). Совершенно очевидно, что молодому Толстому интересен в первую очередь он сам, отсюда императивная

4 Первоначально вместо слова природу было - Бога. Там же. 
установка: «Изучи систему своего существа» (Толстой, 1978-1985, т. 21, с. 21). Этой цели и служит дневник, по которому, как убежден автор, «весьма удобно судить о самом себе» (Толстой, 1978-1985, т. 21, с. 22). Максимальная концентрация на индивидуальном Я, по сути, дала возможность будущему писателю открыть бессрочный проект самопознания - в отношении к своим способностям, чувствам, влечениям, переживаниям, мыслям, поведению и проч.

Важнейшей опорой в этом долгосрочном проекте для Толстого является разум, который он ценит превыше всех других человеческих свойств:

Оставь действовать разум, он укажет тебе на твое назначение, он даст тебе правила, с которыми смело иди в общество. Все, что сообразно с первенствующею способностью человека - разумом, будет равно сообразно со всем, что существует; разум отдельного человека есть часть всего существующего, а часть не может расстроить порядок целого. Целое же может убить часть. Для этого образуй твой разум так, чтобы он был сообразен с целым, с источником всего, а не с частью, с обществом людей; тогда твой разум сольется в одно с этим целым, и тогда общество, как часть, не будет иметь влияния на тебя (Толстой, 1978-1985, т. 21, с. 7).

По словам биографа Петра Бирюкова, разум для Толстого изначально «главный двигатель на пути человека к его совершенствованию» (Бирюков) На первых же страницах дневника юный диарист предстает как личность рациональная, обладающая трезвым взглядом на мир, способная посредством разума контролировать свои природные потребности, а также формировать и развивать способности. Он презентует себя исследователем, познающим мир и его свойства, последовательным аналитиком. Так, 19 марта 1847 Толстой записал в дневнике: «Во мне начинает проявляться страсть к наукам» (Толстой, 1978-1985, т. 21, с. 8); а четверть века спустя - 6 ноября 1873 г. - подтвердил: «Я смолоду стал (...) анализировать все» (Толстой, 1978-1985, т. 21, с. 269). С рациональностью Толстой свяжет способы удовлетворения не только материальных, но и идеальных потребностей, а это, помимо чисто духовных, религиозных интересов, еще и телеологические действия, направленные на реализацию определенных целей. Опираясь на рациональность, диарист осуществляет свой познавательный выбор, акцентуирует те культурные смыслы (искусство, философия, религия и т.д.), которые способны служить духовными ориентирами

5 См.: Лев Толстой в письме к М. О. Меньшикову, от 2-5 октября 1895 г. пишет (Толстой, 1954, т. 68, с. 197): «Разум есть орудие, данное человеку для исполнения своего назначения, или закона жизни, и так как закон жизни один для всех людей, то и разум один для всех, хотя и проявляется в различных степенях в различных людях. Все движение жизни - что называют прогрессом - есть все большее и большее объединение людей в уясненном разумом определении цели, назначения жизни и средств исполнения этого назначения. Разум есть сила, которая дана человеку для указания направления жизни. В наше время цель жизни, указанная разумом, состоит в единении людей и существ: средства же для достижения этой цели, указанные разумом, состоят в уничтожении суеверий, заблуждений и соблазнов, препятствующих проявлению в людях основного свойства их жизни - любви. Вот что такое разум, как я более или менее ясно старался выражать это во всех моих писаниях последних десяти лет». 
в его собственном развитии; он создает свою картину мира, обдумывает свое предназначение в мире.

Идея самосовершенствования, завладев сознанием юного Толстого, обусловила его целенаправленную деятельность по систематическому формированию у себя положительных качеств и ограничению или устранению качеств отрицательных. В сознании диариста самовоспитание, работа над собой непосредственно соотносится с идеей непрестанного развития, поэтому на страницах дневника и в самой жизни он постоянно занят формированием и «развитием своих способностей»: интеллекта, воли, духа, тела, чувств, памяти, а также «развитием из самого себя хорошего», то есть установлением морально-нравственных позиций. По сути дела дневник, отражая стремление Толстого к системному развитию всевозможных мыслительных процессов, фиксирует когнитивность авторского мышления.

Функция дневника при этом трактуется преимущественно утилитарно:

([7] апреля. 8 часов утра.) [1847] Я никогда не имел дневника, потому что не видал никакой пользы от него. Теперь же, когда я занимаюсь развитием своих способностей, по дневнику я буду в состоянии судить о ходе этого развития. В дневнике должна находиться таблица правил, и в дневнике должны быть тоже определены мои будущие деяния (Толстой, 1978-1985, т. 21, с. 12).

Совершенно очевидно, что собственное «я» воспринимается диаристом как предмет саморефлексии и самопроектирования, протекающих в рамках общения / контроля / сравнения с неким идеальным другим, созданным в сознании на основе нормативной «таблицы правил». 7-го марта 1851 г. он запишет: «Нахожу для дневника, кроме определения будущих действий, полезную цель - отчет каждого дня, с точки зрения тех слабостей, от которых хочешь исправиться» (Толстой, 1978-1985, т. 21, с. 31). Сущность личности трактуется как непрерывное стремление к самосовершенству.

Стефан Цвейг остроумно заметил:

В безбородого юношу уже вселился будущий мировой педагог - Толстой, который с самого начала смотрит на жизнь как на „серьезное дело”, которое нужно вести разумно и постоянно контролировать. По-коммерчески он открывает себе счет обязанностей, дебет и кредит намерений и исполнений. О внесенном капитале - своей личности - девятнадцатилетний Толстой судит уже вполне здраво. Он констатирует при первой инвентаризации своих данных, что он „исключительный человек”, с „исключительной” задачей: но вместе с тем этот полумальчик уже немилосердно отмечает, какую громадную силу воли он должен развить, чтобы принудить свою, склонную к лени, неуравновешенности, нетерпению и чувственности натуру к моральным жизненным подвигам (Цвейг, 1992).

С помощью самонаблюдения и самоанализа, регулярно отражающихся в дневнике, вырабатывается авторская self conception (Я-концепция) - некий личный идеал, индивидуально сконструированный стандарт, к которому устремлена личность. Роберт Бернс определяет термин «Я-концепция» как «совокупность всех представлений индивида о себе, (...) связанные как с образом Я, так и с самооценкой» (Бернс, 1986). Я-концепция (конструкт Я) Толстогодиариста выражает восприятие и интерпретацию Я, его свойств, качеств и цен- 
ностей, основываясь не только на реальных фактах, но и на предполагаемых, идеальных формах самосознания. Конструкт-Я становится значимым для Толстого-диариста, обусловливая поведение и оценки его реального Я. Дневниковый текст, как вытекает из замыслов и реальных практик автора, принципиально направлен, с одной стороны, на создание некоего идеала, мыслимого как результат обобщения определенных норм и правил, четко устанавливающих, что и как следует или не следует делать; с другой - на самопознание, максимально адекватное выявление собственной сути. Такая двойственная позиция позволяет диаристу осмыслить себя как другого. Большое место занимают самооценки диариста, ориентированного, как уже отмечалось, на абстрагированный идеал, изменяющийся, как и само его Я. Чаще всего самооценки достаточно жесткие: «в Москве, жил очень безалаберно, без службы, без занятий, без цели (...)» (Толстой, $1978-1985$, т. 21, с. 23). «Живу совершенно скотски; хотя и не совсем беспутно, занятия свои почти все оставил и духом очень упал» (Толстой, 1978-1985, т. 21, с. 27), значительно реже - позитивные: «заметил в себе я еще важную перемену: я стал более уверен в себе, (...) я мог себя оценять и приобрел сознание своего достоинства» (Толстой, 1978-1985, т. 21, с. 25). Толстой выступает автором автобиографического текста, а также создателем определенных способов восприятия, понимания, трактовки, презентации (в том числе и автомифологизации) собственного Я.

Толстой-диарист устремлен в будущее, дневник и задуман, по признанию автора, для определения «будущих деяний» (Толстой, 1978-1985, т. 21, с. 12). С юности он создает, вырабатывает, постоянно уточняет и перерабатывает стратегию замысла своей жизни, но при этом изначально намечает генеральную линию относительно общей «цели жизни человека» вообще, видя ее, как следует из записи от 17 апреля 1847 г., во «всевозможном способствовании к всестороннему развитию всего существующего» (Толстой, 1978-1985, т. 21, c. 13). Толстой, как свидетельствует его дневник, старается правильно организовать свою жизнь, поэтому напряженно продумывает, осмысливает свое бытие и детали быта, конструирует проекты самосотворения, которые, несмотря на многочисленные препятствия и противоречия, пытается хотя бы частично реализовать на практике. С помощью системы индивидуальных «правил» ${ }^{6}$ он старается понять, проанализировать, истолковать, проконтролировать и свои, как указывает, немногочисленные достоинства (к которым относит ум и честность), и многочисленные, как считает, недостатки; он стремится усовершенствовать

6 См., например, правила, сформулированные в 1847 г.:

5. Правила для развития воли телесной

6. Правила для развития воли чувственной

7. Правила для развития воли разумной

8. Правила для развития памяти

9. Правила для развития деятельности

10. Правила для развития умственных способностей

11. Правила для развития чувств высоких и уничтожения чувств низких, или иначе: правила для развития чувства любви и уничтожения чувства самолюбия

12. Правила для развития обдуманности (Толстой, 1978-1985, т. 21, с. 15-21). 
себя как личность и в конечном итоге выработать из себя «совершенного человека». Индивидуальные «правила» Толстого - это своего рода личностные конструкты для развития разнообразных свойств и качеств, прежде всего - воли, деятельности, памяти, умственных способностей. Так, формулируя Правила для развития умственных способностей, автор исходит из того, что человеку присущи «пять главных умственных способностей. Способность представления, способность памяти, способность сравнения, способность делать выводы из этих сравнений и, наконец, способность приводить выводы эти в порядок» (Толстой, 1978-1985, т. 21, с. 20). Соответственно этой классификации, вырабатывает (март - май 1847 г.) совокупность конкретных императивных установок, направленных на достижение определенных знаний, умений, навыков. Приведу в качестве примеров некоторые из них:

35) Изучай хорошо те предметы, которые ты сравниваешь.

36) Всякую новую тебе встретившуюся мысль сравнивай с теми мыслями, которые тебе известны. Все отвлеченные мысли оправдывай примерами. (...)

36) Занимайся математикой.

37) Занимайся философией.

38) Всякое философическое сочинение читай с критическими замечаниями. (...)

39) Изучи систему своего существа.

40) Все твои сведения по одной какой-нибудь отрасли знания приведи к одному общему выводу.

41) Все выводы сравни между собою, и чтобы ни один вывод не противоречил другому.

42) Пиши сочинения не мелкие, но ученые (Толстой, 1978-1985, т. 21, с. 21).

Автор вместе с четкими установками по формированию определенных свойств и качеств, которыми должна, в его понимании, обладать совершенная личность, строго рассматривает и оценивает ход своего физического, интеллектуального и нравственного развития. При этом идеальное Я соотносится с реальным Я и теми целями, с которыми автор связывает свое будущее:

- 24 марта. 1847. Я много переменился; но все еще не достиг той степени совершенства (в занятиях), которого бы мне хотелось достигнуть. Я не исполняю того, что себе предписываю; что исполняю, то исполняю не хорошо (...) (Толстой, 1978-1985, т. 21, с. 9)

- (8 апреля. 6 часов утра.) 1847 (...) Хотя я уже много приобрел с тех пор, как начал заниматься собою, однако еще все я весьма недоволен собою. Чем далее подвигаешься в усовершенствовании самого себя, тем более видишь в себе недостатков (...) (Толстой, $1978-1985$, т. 21, с. 13$)$

- 9 апреля (6 часов утра). Я совершенно доволен собою (...) (Толстой, 1978-1985, т. 21, 13)

- 17 апреля. Все это время я вел себя не так, как я желал себя вести (Толстой, 1978-1985, т. 21, c. 13).

В дневнике закладываются основы толстовской системы самовосприятия, базирующейся на соотнесении трех Я: в прошлом, настоящем и будущем. Поведение, поступки, действия, размышления «Я в настоящем» оцениваются в соотнесении с преодолеваемым негативным «Я в прошлом» и идеально перспективным «Я в будущем». Развитие личности в различных направлениях - на 
интеллектуальном, эмоциональном, чувственном уровнях, обусловливает как характер восприятия реальности, так и способ мышления.

На первых же страницах дневника Толстой стремится уяснить и установить главную цель всей своей жизни. Такая цель была сформулирована им в записи от 17 апреля 1847 г. Это цель не просто высокая, но высочайшая - универсальная, фундаментальная, онтологическая, направленная на такое развитие собственной «бессмертной души», которое позволит «естественно перейти в существо высшее и соответствующее ей» (Толстой, 1978-1985, т. 21, с. 14). С этого момента жизнь диариста должна стать «вся стремлением деятельным и постоянным к этой одной цели» (Толстой, 1978-1985, т. 21, с. 14); «в человеке, который не зависит ни от какого постороннего влияния, дух необходимо по своей потребности превзойдет материю, и тогда человек достигнет своего назначения» (Толстой, 1978-1985, т. 21, с. 15). Согласно Толстому, душа человека в процессе непрестанного развития совершенствуется, обретая способность переходить в дух, олицетворяя в нем образ Бога. Писатель конструирует и интерпретирует цель жизни в аспекте общеполезности, все свои усилия он намеревается направить на то, чтобы делать добро ближнему. Устремленность к свершению добра для другого, нацеленность на позитивную социализацию обусловливают аксиологическую и телеологическую значимость толстовских интенций.

Определив общую, глобальную цель жизни, Толстой намечает весьма разветвленную систему самых разнообразных норм и правил, с помощью которой намеревается достичь положительного результата. Совершенно очевидно стремление автора последовательно, соответственно времени, месту, возрасту, ставить и решать конкретные задачи по самосовершенствованию на всех жизненных этапах. Он устанавливается с самим собой: «имей цель для всей жизни, цель для известной эпохи твоей жизни, цель для известного времени, цель для года, для месяца, для недели, для дня и для часу и для минуты, жертвуя низшие цели высшим» (Толстой, 1978-1985, т. 21, с. 19). Поставив цель, диарист анализирует ситуацию, в которой ему предстоит действовать, выбирает способы и средства для достижения цели, намечает возможные «деяния» (поступки) и их последовательность. Цель, ситуация, условия осуществления задуманных акций формируют на конкретном жизненном этапе некую идеальную схему деятельности.

Так, в 1847 г., уезжая из Казани в Ясную Поляну, Толстой формулирует задачи на ближайшие два года жизни в деревне (Толстой, 1978-1985, т. 21, с. 14):

1) Изучить весь курс юридических наук, нужных для окончательного экзамена в университете.

2) Изучить практическую медицину и часть теоретической.

3) Изучить языки: французский, русский, немецкий, английский, итальянский и латинский.

4) Изучить сельское хозяйство, как теоретическое, так и практическое.

5) Изучить историю, географию и статистику.

6) Изучить математику, гимназический курс.

7) Написать диссертацию.

8) Достигнуть средней степени совершенства в музыке и живописи. 
9) Написать правила.

10) Получить некоторые познания в естественных науках.

11) Составить сочинения из всех предметов, которые буду изучать.

Амбициозные цели молодого Толстого, мощно подтолкнувшие его к саморазвитию, лишь на первый взгляд кажутся несбыточными. По существу почти вся намеченная программа оказалась выполненной, хотя и не за два года, как первоначально предполагалось, а в течение всей жизни. Ненаписанная диссертация (пункт 7) вполне компенсируется той грандиозной литературной деятельностью, в которой реализовался Толстой как писатель.

Толстовская когнитивная Я-концепция связывает процесс самопознания с опытом классификации и интерпретации фактов действительности, а также с попытками прогнозирования будущего. Приняв в качестве доминанты положение о решающей роли знания в человеческой жизни, Толстой создает на этой основе нормативные эталоны, личностные конструкты, когнитивные схемы для понимания собственного характера, психики и поведения.

Автор ранних дневников много размышляет о разуме, теле, воле, любви, страхе, жизненных целях, развитии, совершенстве и проч. Есть в этих дневниках и признания диариста, касающиеся вопросов веры и религии. При этом существенно то, что накапливаемые знания не противостоят его вере.

В записи от 12 июня 1851 Толстой описал свой юношеский опыт «общего чувства» единения с «существом всеобъемлющим», пережитую им «блаженную минуту» в состоянии полного благоговения:

Вчера я почти всю ночь не спал, пописавши дневник, я стал молиться богу. Сладость чувства, которое испытал я на молитве, передать невозможно. Я прочел молитвы, которые обыкновенно творю: Отче, Богородицу, Троицу, Милосердия Двери, воззвание к ангелухранителю и потом остался еще на молитве (Толстой, 1978-1985, т. 21, с. 43).

По учению отцов Церкви, «молитва есть беседа ума к Богу», «проявление радости и благодарения», «восхищение ума, (...) когда неизглаголанными воздыханиями духа приближается он к Богу» (Синайский, 1998). Сладость молитвы не во власти человека, а дар Божий; главное в молитве - близость сердца к Богу; не ум доминирует, а именно сердце, потому что в сердце заключается вся полнота человеческой личности. Когда человек молится сердцем, то он весь молится Богу (см. об этом: Молитвы, 1997, с. 140-146). Возвышенное молитвенное состояние заключается «в созерцании единого Бога и в пламенной любви к Нему, и где ум наш, объятый и проникнутый сею любовью, беседует с Богом ближайшим образом и с особенной искренностью» (св. Иоанн Кассиан Римлянин, 1895). Толстому известно, что по содержанию молитвы подразделяются на хвалебные, покаянные, просительные, благодарственные и др. В дневнике он пытается осознать внутренние ощущения, переживаемые им в состоянии молитвы:

Ежели определяют молитву просьбою или благодарностью, то я не молился. Я желал чегото высокого и хорошего; но чего, я передать не могу; хотя и ясно сознавал, чего я желаю. Мне хотелось слиться с существом всеобъемлющим. Я просил его простить преступления мои; но нет, я не просил этого, ибо я чувствовал, что ежели оно дало мне эту блажен- 
ную минуту, то оно простило меня. Я просил и вместе с тем чувствовал, что мне нечего просить и что я не могу и не умею просить. Я благодарил, да, но не словами, не мыслями. Я в одном чувстве соединял все, и мольбу и благодарность. Чувство страха совершенно исчезло. Ни одного из чувств веры, надежды и любви я не мог бы отделить от общего чувства. Нет, вот оно чувство, которое испытал я вчера - это любовь к богу. Любовь высокую, соединяющую в себе все хорошее, отрицающую все дурное (Толстой, 1978-1985, т. 21, c. 43$)$.

Автор стремится передать то необыкновенное религиозное блаженство (сладость чувства на молитве), которое он испытал в молитвенном состоянии сознания. В Новом Завете сказано: Бог есть высшее благо и источник блаженства (1 Тим 1. 11; 6. 15) (Библия, 1988, с. 252, 256); блаженство человека состоит в единении с Богом в любви. Это состояние и захватывает все существо диариста, поглощает его разум, чувства, интенции. Он как бы следует сентенции преподобного Иоанна Лествичника, который учил: «Если ты в каком-либо слове молитвы почувствуешь особенную сладость или умиление, то остановись на нем, ибо тогда и Ангел-хранитель наш молится с нами» (Лествичник, online). В молитвенном состоянии благодать просвещает душу, сердце и совесть человека, под ее воздействием исчезает страх и все то, что мешает постичь истинную суть жизни и самого себя. В общем, едином чувстве соединяются вера, надежда и любовь. Только полностью отрешившись от всего мирского, в состоянии молитвенного блаженства человек способен, как напишет Толстой, «вызвать в себе божественную часть своей души, перенестись в нее, посредством нее вступить в общение с Тем, Кого она есть частица (...)» (Толстой, 1954, т. 73, с. 12). Однако ограниченность человеческого опыта и познания не позволяет ему в полной мере понять и представить суть истинного блаженства, поскольку полнота блаженства возможна только в вечности. Самая же земная жизнь человека наполнена страданиями. Отсюда констатация противоречий, сомнения:

12 июня 1851: Вечное блаженство здесь невозможно. Страдания необходимы. Зачем? не знаю. И как я смею говорить: не знаю. Как смел я думать, что можно знать пути провидения. Оно источник разума, и разум хочет постигнуть... Ум теряется в этих безднах премудрости, а чувство боится оскорбить его. Благодарю его за минуту блаженства, которая показала мне ничтожность и величие мое. Хочу молиться; но не умею; хочу постигнуть; но не смею - предаюсь в волю твою! Зачем писал я все это? Как плоско, вяло, даже бессмысленно выразились чувства мои; а были так высоки! (Толстой, 1978-1985, т. 21, с. 44).

Автор с горечью осознает ограниченность человеческого разума (неисповедимость путей провидения), не способного полноценно понять ни хода исторических событий, ни причинно-следственных связей собственного бытия. Человек владеет Божьим даром - определенным разумом, способностью познания (разумения) и самим знанием. Но высшая мудрость, премудрость, всеведение -свойство самого Бога. Пережитая минута блаженства вознесла диариста на вершину абсолютного счастья, но и дала возможность осознать двойственность природы человека: «ничтожность и величие», способность высокого чувствования и невозможность его адекватного словесного выражения (плоско, вяло, бессмысленно). 
В записи от 18 июля 1852 Толстой упоминает о потребности в просительной молитве:

... Я молюсь так: боже, избави меня от зла, то есть избави меня от искушения творить зло, и даруй мне добро, то есть возможность творить добро. Буду ли я испытывать зло или добро? - да будет воля твоя! - Неужели я никогда не выведу понятие о боге так же ясно, как понятие о добродетели? Это теперь мое сильнейшее желание (Толстой, 1978-1985, т. 21, c. 77$)$.

В представлении Толстого, человек постоянно изменяется, следовательно, изменяется и уточнятся его отношение к Богу. Теперь сильнейшее желание диариста состоит в том, чтобы «вывести понятие о боге». Он хочет мыслить Бога, человека, мир посредством ясных и точных понятий, опираясь на разум, логику, причинно-следственные связи. Запись от 17 августа 1852 г. свидетельствует, что Толстой, пытаясь рационально уяснить понятие Бога, выдвигает даже некую «гипотезу» о существовании бесконечного Бога, сотворившего все живое:

Ничто не убедило меня в существовании бога и наших отношений к нему, как мысль, что способности всем животным даны сообразно с потребностями, которым они должны удовлетворять. Ни больше, ни меньше. Для чего же дана человеку способность постигать: причину, вечность, бесконечность, всемогущество? Положение это (о существовании бога) - гипотеза, подтвержденная признаками. Вера, смотря по степени развития человека, дополняет ее правдивость (Толстой, 1978-1985, т. 21, с. 78-79).

Для Толстого понять что-либо - значит, объяснить, то есть связать изучаемый предмет с другим, вывести из этого другого и таким образом обнаружить причинно-следственные связи. Понять «существо всеобъемлющее» - Бога - значит, вывести его из некой причины, которой он обусловлен. Но тогда бог перестает быть Богом... Однако существуют непосредственные истины первичного достояния ума, не требующие доказательств. Такими аксиомами у Толстого выступают: «мысль, что способности всем животным даны сообразно с потребностями»; человеку дана «способность постигать». Обращение к истинам, не требующих доказательств, отказ от выявления причинно-следственных связей свидетельствует об отходе от научного, логического мышления. Там, где молчит человеческий разум, слово берет вера. Толстой совершенно сознательно отделил сферу веры от сферы знания. Однако необходимость веры в Бога он будет доказывать логическими средствами. Необходимость существования всеобъемлющего Бога обусловливается им целесообразностью, обусловливающей смысл человеческой жизни и всемирного бытия.

Раздумья о Боге и вере привели диариста к феноменальному замыслу, зафиксированному в дневниковой записи от 2, 3, 4 марта 1855 г.:

... Вчера разговор о божественном и вере навел меня на великую громадную мысль, осуществлению которой я чувствую себя способным посвятить жизнь. Мысль эта - основание новой религии, соответствующей развитию человечества, религии Христа, но очищенной от веры и таинственности, религии практической, не обещающей будущее блаженство, но дающей блаженство на земле. Привести эту мысль в исполнение я понимаю, что могут только поколения, сознательно работающие к этой цели. Одно поколение будет завещать мысль эту следующему, и когда-нибудь фанатизм или разум приведут ее 
в исполнение. Действовать сознательно к соединению людей с религией, вот основание мысли, которая, надеюсь, увлечет меня (Толстой, 1978-1985, т. 21, с. 139-140).

Именно эта грандиозная цель: основание новой, единой для всего человечества религии, и будет занимать сознание писателя на протяжении всей его последующей жизни.

Ранние дневники Толстого, безусловно, самостоятельные тексты, обладающие своими особенностями, но в то же время отдельные записи, содержащиеся в них, являются претекстами для различных документальных и художественных произведений писателя. На разных жизненных этапах Толстой, как известно, читал и перечитывал свои дневники («они - я. Они доставляют мне благо»); некоторые проблемы, затронутые ранее, акцентуирует вновь и вновь. В частности, вопросы самопознания, рассуждения о вере, религии и Боге, получивших выражение в ранних дневниках (1847-1855), выступают в качестве значимого автопретекста для толстовской Исповеди (1879-1882). При этом очевидны константы и эволюция творческого сознания писателя. В конце 1870-х гг. в период мировоззренческого перелома ряд первоначальных установок и суждений остается неизменным (самоосознание, самопознание, целеполагание), некоторые - пересматриваются, пере/о-смысливаются или даже переменяются (религия, вера), но в любом случае актуализируются и остаются значимыми впоследствии.

\section{Библиография}

Балдин, А. А. (2000). «Исповедь» Л. Н. Толстого и его произведения 1880-1890-х гг. Известия Уральского государственного университета, № 17, Серия 2, Гуманитарные науки, с. 24-32.

Бернс, Р. (1986). Развитие Я-кониепции и воспитание. Пер. с англ. М. Б. Гнедовский, М. А. Ковальчук. Общ. ред., вступ. статья. В. Я. Пилиповского. Москва: Прогресс, Online: http:// psyberlink.flogiston.ru/internet/bits/burns0.htm (2.07.2018).

Бибихин, В. (2012). Дневники Льва Толстого. Санкт-Петербург: Издательство Ивана Лимбаха. Бибихин, В. В. (2014). Дневники Льва Толстого. В: Гусейнов, А. А., Щедрина, Т. Г. (ред.). Лев Николаевич Толстой. Москва: Политическая энциклопедия, с. 48-76.

Библия. Книги Священного Писания Ветхого и Нового Завета. Канонические (1988). Москва: Всесоюзный Совет ЕХБ.

Бирюков, П. И. Биография Л. Н. Толстого, т. 3, ч. 1. Online: http://lib-ru.do.am/publ/tolstoj_ lev_nikolaevich_birjukov_p_i_biografija_1_n_tolstogo_tom_3_3_ja_chast_stranica_2/1-1-0-3 (2.07.2018).

Булдакова, Ю. М. (2005). „Борьба с недобрым чувством” Л. Н. Толстого. В: Труды кафедры русской литературы: анализ художественного текста. Киров: КГУ, с. 77-88.

Бушканец, Л. (2006). „Дневники” молодого Толстого как нарративный текст. В: Dzienniki pisarzy rosyjskich. Warszawa: „Studia Rossica”, c. 165-177.

Галаган, Г. Я. (2000). Дневник молодого Л. Толстого и его философско-историческая кониепиия. В: Щербакова, М. И. (ред.). Мир филологии. Москва, с. 188-194.

Галаган, Г. Я. (2007). Дневники молодого Л. Толстого и его концепция жизнепониманий. B: Dzienniki, notatniki i listy pisarzy rosyjskich. Warszawa: „Studia Rossica”, c. 8-9.

Гусев, Н.Н. (1970). Лев Николаевич Толстой. Материаль к биографии с 1881 по 1885 год. Отв. ред. Л. Д. Опульская и А. И. Шифман. Москва: АН СССР ИМЛИ. 
Густафсон, Р. Ф. (2003). Обитатель и Чужак. Теология и художественное творчество Льва Толстого. Пер. с англ. Т. Бузиной. Санкт-Петербург: Академический проект.

Добротолюбие (1998): в 5 m. Т. 2. Москва: Паломник. Online: https://azbyka.ru/otechnik/prochee/dobrotoljubie_tom_2/17 (04.07.2018).

Егоров, О. Г. (2002). Лев Николаевич Толстой. В: Егоров, О. Г. Дневники русских писателей ХІХ века. Исследование. Москва: Флинта, с. 158-192.

Закон Божий (1997). Т. 1, кн. 1-3, Москва: Терра - Terra.

Зассе, С. (2012). Яд в ухо. Исповедь и признание в русской литературе. Пер. с нем. Б. Скуратова, И. Чубарова. Москва: РГГУ.

Зеньковский, В. В. История русской философии: в 4 m. Т. 1, ч. 2. Сост. В. А. Поляков, Ленинград: «Эго» 1991.

Иоанн Кассиан Римлянин, св. (1895). О молитве. В: Добротолюбие. Т. 2. Москва. Online: http:// www.odinblago.ru/dobrotolubie_2/ioann_kassian/o_molitve (1.06.2018).

Лествичник, Иоанн. Слово 28. О матери добродетелей, священной и блаженной молитве, и о предстоянии в ней умом и телом. В: Лествичник, Иоанн. Лествица. Online: https:// www.ccel.org/contrib/ru/Lestviza/Lest28.htm (02.07.2018).

Луцевич, Л. (2010). «Исповедь» Л. Н. Толстого: анализ, покаяние, поиски истины веры. Slawia Orientalis, т. 59, № 4, с. 467-486.

Луцевич, Л. (2017). «Исповедь» Л. Н. Толстого. В: Рецепция личности и творчества Льва Толстого: коллективная монография. Сост. и науч. ред. Л. Е. Бушканец. Казань: Изд-во Казанского ун-та, с. 7-37.

Мережковский, Д. С. (1995). Л. Толстой и Достоевский. Вечные спутники. Подгот. текста М. Ермолаева, комм. А. Архангельской. Москва: Республика.

Молитвы. В: Закон Божий, т. 1, кн. 1-3. Москва: Терра, 1997, с. 140-146.

Ореханов, Г., прот. (2016). Лев Толстой «пророк без чести». Хроника катастрофы. Москва: Эксмо.

Паперно, И. (2003). „Если бы можно было рассказать себя...”: дневники Л.Н. Толстого. Пер. с анг. Б. Маслова. Новое титературное обозрение, № 61, с. 296-317.

Петровицкая, И. В. (2009). Исповедь и проповедь Льва Толстого. В: Лев Толстой. Дневники. Записные книжки. Статьи. 1908 г. Сост., предисл., комм., прилож. И. В. Петровицкой. Под общ. ред. В. Я. Линкова. Москва: Изд-во: ВК, с. 5-22.

Пиотровска, И. (2007). Ранние дневники (1847-1856) Льва Толстого: функциональная направленность. В: Русская филология: сборник научных работ молодых филологов. Т. 18, Тарту: Тартуский университет, с. 39-43.

Пиотровска, И. (2008). Европа и европейцы в ранних дневниках Льва Толстого. В: Slavistika dnes: vlivy a kontexty. Konference mladých slavistů. Praha: Červený Kostelec, c. 503-512.

Пиотровска, И. (2008). Ранняя диаристика Льва Толстого: Автомифологизация через негативы. Studia Slavica, т. 8. (Таллинн: OU Vali Press), c. 47-55.

Пиотровска, И. (2008). Некоторые аспекты соотномения ранних дневников Л. Толстого с европейскими источниками. В: Русская литература в европейском контексте 1. Warszawa: Instytut Rusycystyki Uniwersytetu Warszawskiego, c. 93-100.

Седакова, О. А. (2014). Весть Льва Толстого. Вступительные замечания к курсу В.В. Бибихина «Дневники Льва Толстого». В: Лев Николаевич Толстой. Под ред. А. А. Гусейнова, Т. Г. Щедриной. Москва: Политическая энциклопедия, с. 35-47.

Тарасов, Б. Н. (2014). Л. Н. Толстой о человеке, разуме и науке, демократии, изиилизации и прогрессе (“Диалог писателя на страницах „Дневника” с современниками и потомками). В: Лев Николаевич Толстой. Под ред. А. А. Гусейнова, Т. Г. Щедриной. Москва: Политическая энциклопедия, с. 77-109. 
Толстой, Л. Н. (1978-1985). Собрание сочинений: в 22 m. Гл. ред. М. Б. Храпченко. Москва: Художественная литература.

Толстой, Л. Н. (1937). Полное собрание сочинений: в 90 m. Т. 46: Дневник 1847-1854. Под общ. ред. В. Г. Черткова. Москва: Государственное издательство «Художественная литература».

Толстой, Л. Н. (1954). Полное собрание сочинений: в 90 m. Т. 68: Письма 1895. Подг. текста и комм. А. С. Петровского. Москва: Государственное издательство художественной литературы.

Толстой, Л. Н. (1954). Полное собрание сочинений: в 90 m. Т. 73: Письма 1901-1902. Подг. текста и комм. В. А. Жданова. Москва: Государственное издательство художественной литературы.

Цвейг, С. (1992). Три певиа своей жизни: Казанова. Стендаль. Толстой. Пер. с нем. П. С. Бернштейна. Род ред. Б. М. Эйхенбаума. Москва: Республика, Online: http://philologos.narod.ru/ texts/zweig_tolstoyF.htm (11.06.2018).

Эйхенбаум, Б. (1922). Молодой Толстой. Москва; Берлин: Издательство 3. И. Гржебина.

Gazdecka, E. (2006). Lew Tołstoj - samoocena i rzeczywistość. Wyjątki z Dzienników. B: Wołodźko-Butkiewicz, A., Łucewicz, L. (ред.). Dzienniki pisarzy rosyjskich. (Серия „Studia Rossica”, т. 17). Warszawa: Studia Rossica”, c. 179-186.

Semczuk, A. (2004). Młody Lew Tołstoj krytykuje Katarzynę 2. B: Wołodźko-Butkiewicz, A. (red.). Rosja literacka: od Karamzina do Sołżenicyna: księga poświęcona Profesorowi Tadeuszowi Szyszko z okazji 45-lecia pracy naukowej. (Серия „Studia Rossica”, т. 15). Warszawa: „Studia Rossica”, c. 117-123. 